\title{
Crystallization and layer formation in the middle zone of the Skaergaard Intrusion
}

\author{
H. R. NASLUND, P. A. TURNER and D. W. KEITH
}

\begin{abstract}
Naslund, H. R., Turner, P. A. and Keith, D. W.: Crystallization and layer formation in the middle zone of the Skaergaard Intrusion. Bull. geol. Soc. Denmark, vol. 38, pp. 165--171, Copenhagen, February 18th, 1991. https://doi.org/10.37570/bgsd-1990-38-16
\end{abstract}

\begin{abstract}
Macro-rhythmic layering and modally-graded layering in a $23.3 \mathrm{~m}$ thick section of the middle zone of the Skaergaard intrusion were examined in detail. The macro-rhythmic layers form a sequence of alternating plagioclase-rich and pyroxene-rich layers with sharp upper and lower boundaries that range in thickness from 0.3 to $3.3 \mathrm{~m}$ and can be traced laterally for over $2 \mathrm{~km}$. The pyroxene-rich layers have coarser grain sizes, contain higher excluded trace element concentrations, and more Ti-rich opaques than do the plagioclase-rich layers but the compositions of the major silicate minerals are similar in the two layer types. The pyroxene-rich layers may represent periods of increased convection in the magma chamber, while the plagioclase-rich layers represent periods of magma stagnation. Modally-graded layers have sharp lower contacts, gradational upper contacts, and are graded from an opaque oxide-rich base to a more plagioclase-rich top. They range in thickness from 1 to $10 \mathrm{~cm}$ and can not be traced laterally for more than $30 \mathrm{~m}$ in outcrop. The modally-graded layers are parallel to the macro-rhythmic layer boundaries and occur in both plagioclase-rich and pyroxene-rich macro-rhythmic layers. The modally-graded layers may be related to intermittent density currents slumping off the walls of the magma chamber.
\end{abstract}

H.R. Naslund, Department of Geological Sciences, SUNY, Binghamton, NY 13901 USA, P. A. Turner, Department of Earth Sciences, Dartmouth College, Hanover, NH, 03755 USA, and D. W. Keith, Manville Sales Corporation, P.O. Box 287, La Grande, Oregon, 97850 USA, October 15th, 1987.

\section{Introduction}

Layering is an ubiquitous feature in the floor, wall, and roof sequences of the Skaergaard intrusion. A number of distinct types of layering have been described (Wager \& Brown; McBirney \& Noyes 1979; Irvine 1980a, 1980b, 1982, 1983a, 1983b; Conrad, 1982) suggesting that there are a number of different processes by which igneous layering can form. At least two distinct types of layering are present in the middle zone of the Skaergaard intrusion: 1) alternating plagioclaserich and pyroxene-rich macro-rhythmic layers, and 2) smaller scale modally-graded layers.

\section{Field relationships}

This report examines a $23.3 \mathrm{~m}$ thick section of the middle zone on the north end of Kraemer island that contains at least 11 macro-rhythmic layers and 121 modally-graded layers (fig. 1). The boundaries between the macro-rhythmic layers are not easily recognized in outcrop but are read- ily apparent when the rocks are viewed from a distance of a kilometer or more. The layers are visible on weathered outcrop because the pyroxene-rich layers contain $1-4 \%$ olivine formed during subsolidus reaction between magnetite and augite, while the plagioclase-rich layers are generally olivine-free. Weathering of the olivine results in iron staining on the pyroxene-rich layers. The boundaries of 11 macro-rhythmic layers were first determined by observation from a distance of $200 \mathrm{~m}$ and were then marked on the section to be measured. The modal \% of opaque oxides in each $\mathrm{cm}$ of the section was then estimated. Examination of the modal data (fig. 1) suggests that some of the individual macro-rhythmic layers selected in the field may encompass more than one macro-rhythmic layer. Layer two for example may represent a sequence of three pyroxene-rich layers and two plagioclase-rich layers. Layer eleven may represent a lower plagioclase-rich layer and an upper pyroxene-rich layer. A sample collected from the upper part of layer 11 (KØMZ11) is more similar to samples from other pyroxene-rich layers, than to samples from plagioclase-rich layers. 

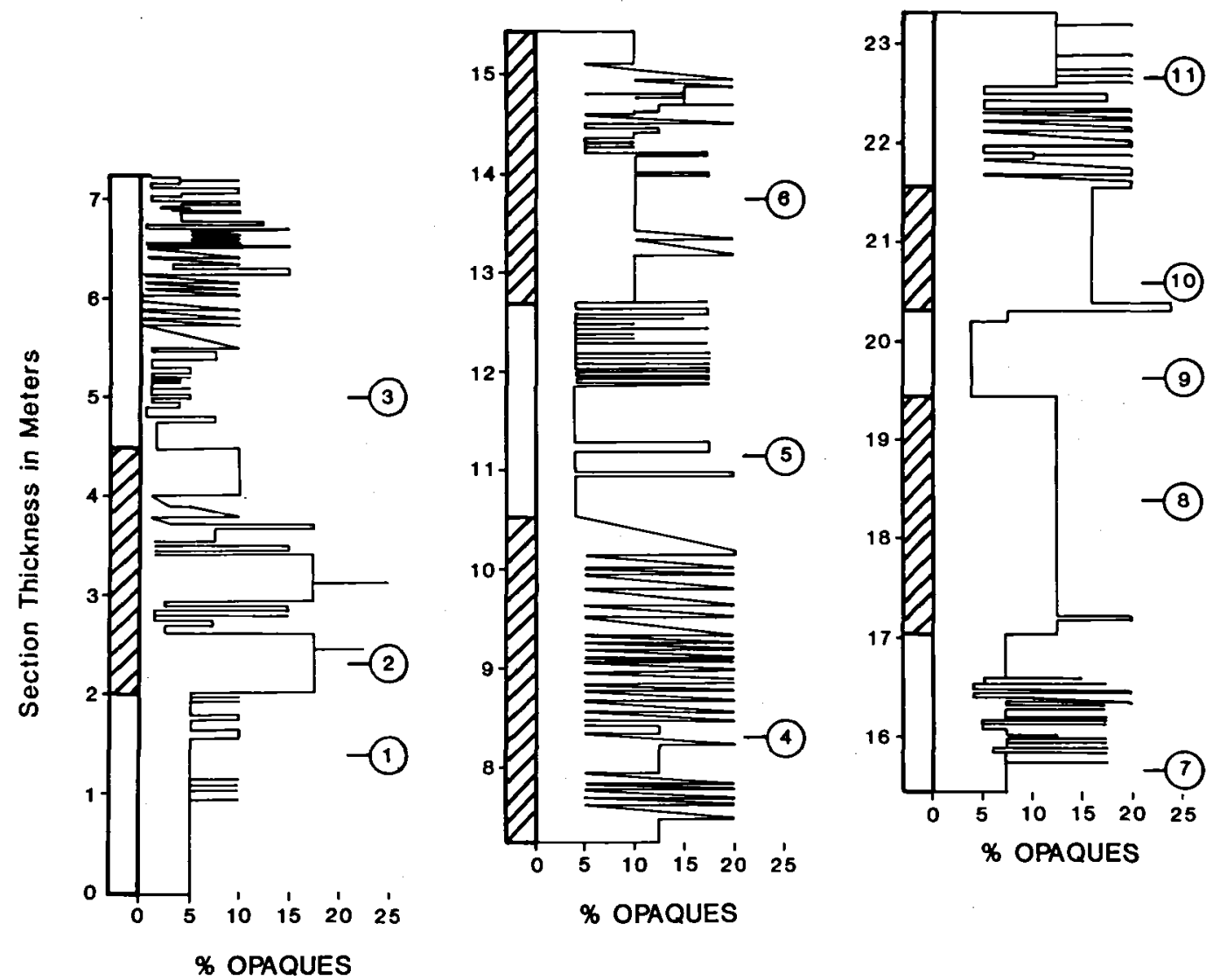

Fig. 1. Variations in the modal abundance of opaque oxides in a $23.3 \mathrm{~m}$ section of the middle zone of the Skaergaard intrusion. Circled numbers refer to samples $\mathrm{K} \emptyset \mathrm{MZ1}$ to $\mathrm{K} \emptyset \mathrm{MZ11}$.

\section{Macro-rhythmic layers}

The macro-rhythmic layers examined range from $0.3 \mathrm{~m}$ to $3.3 \mathrm{~m}$ thick, have sharp upper and lower boundaries, and are not internally graded. Individual layers are generally of uniform thickness and many can be traced laterally for over $2 \mathrm{~km}$ in outcrop. Plagioclase-rich layers, on the average, contain more plagioclase ( $59 \%$ vs $31 \%$ ), less pyroxene ( $30 \%$ vs $48 \%$ ), less opaques ( $9 \%$ vs $17 \%$ ) (fig. 2), and a higher proportion of ilmenite to magnetite than do pyroxene-rich layers. There are no systematic differences in the compositions of plagioclase or augite between the two layer types, but pyroxene-rich layers contain more Tirich ilmenite, more Ti-rich magnetite, and more Ca-rich pyroxene lamellae in exsolved pigeonites than do plagioclase-rich layers (fig. 3). The systematic differences in opaque oxide composition between adjacent layers are thought to be the result of subsolidus re-equilibration, and to reflect the higher magnetite-ilmenite ratios in the pyroxene-rich samples. The lack of compositional zoning in plagioclase and pyroxene suggests that they have also undergone subsolidus re-equilibration. The composition of exsolution lamellae in pigeonite yield equilibration temperatures of $700-850^{\circ} \mathrm{C}$ in the plagioclase-rich layers and $850-910^{\circ} \mathrm{C}$ for the pyroxene-rich layers using the geothermometer of Lindsley (1983). Average grain sizes for both plagioclase and pyroxene are systematically larger $(\sim 15 \%)$ in the pyroxenerich layers (fig. 4). On average, the pyroxene-rich layers contain higher concentrations of $\mathrm{Mg}, \mathrm{Sc}$, $\mathrm{Ti}, \mathrm{Fe}$ and $\mathrm{Co}$ and lower concentrations of $\mathrm{Na}$, $\mathrm{Al}, \mathrm{Si}, \mathrm{K}$ and $\mathrm{Sr}$ than do the plagioclase-rich layers, reflecting their modal differences (Table 1). The concentration of excluded elements (P, 


\section{Modal Abundances}
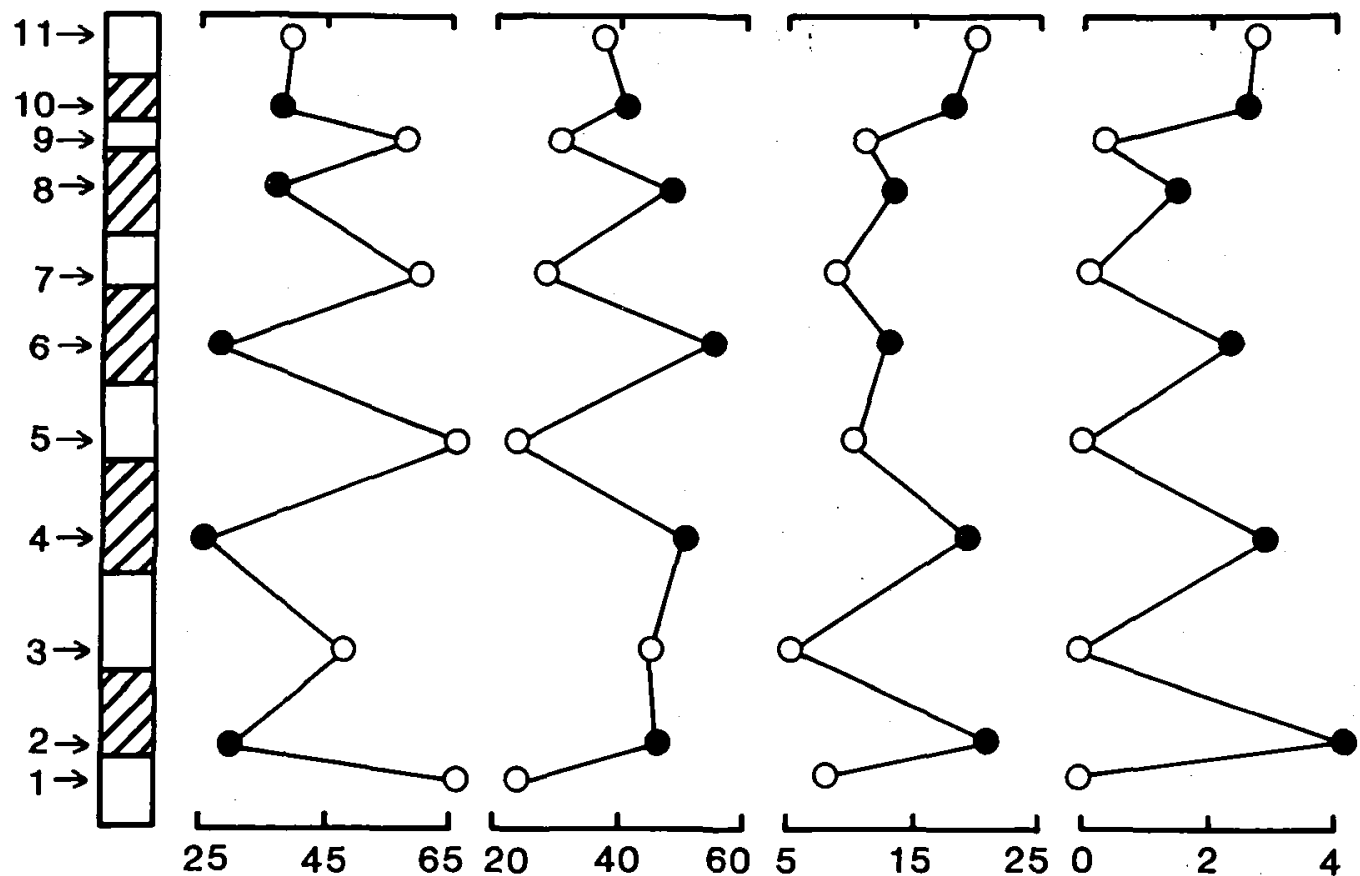

\% Plagioclase

\% Pyroxene

$\%$ Opaques

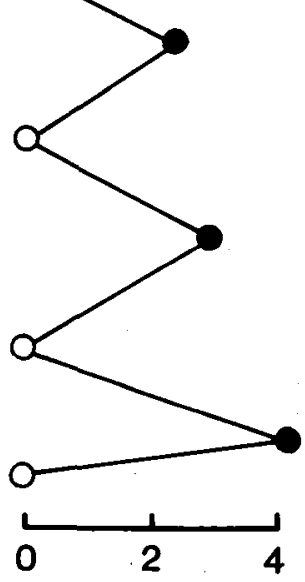

\% Olivine

Fig. 2. Modal abundances of plagioclase, pyroxene, opaques and olivine in samples KØMZ1 to KØMZ11. Open circles are samples identified in the field as plagioclase-rich macro-rhythmic layers; filled circles are samples of pyroxene-rich macro-rhythmic layers.

$\mathrm{Rb}, \mathrm{Zr}, \mathrm{Cs}$ ) is higher in the pyroxene-rich layers than in the plagioclase-rich layers indicating that the plagioclase-rich samples contain significantly less trapped liquid. Igneous lamination in the form of aligned plagioclase and pyroxene laths is best developed in the plagioclase-rich layers.

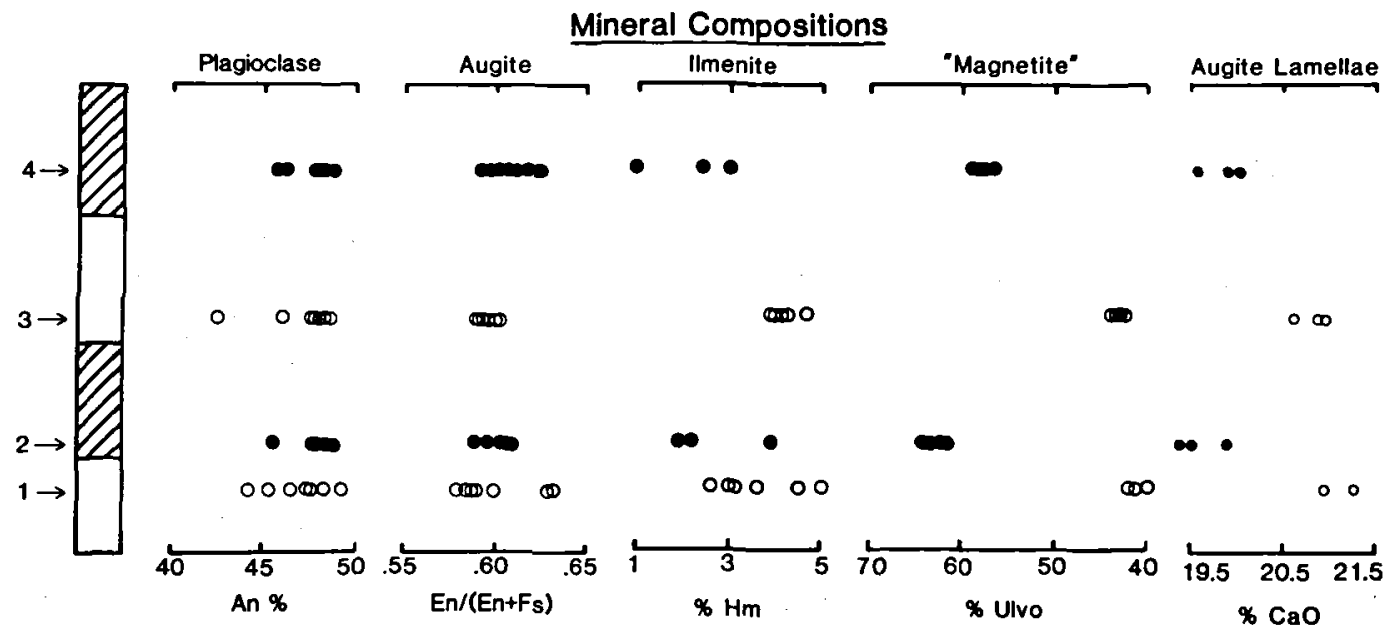

Fig. 3. Microprobe analyses of plagioclase, augite, ilmenite, magnetite, and augite lamellae in pigeonite hosts from samples $\mathrm{K} \emptyset \mathrm{MZ1}$, 2,3 and 4. 


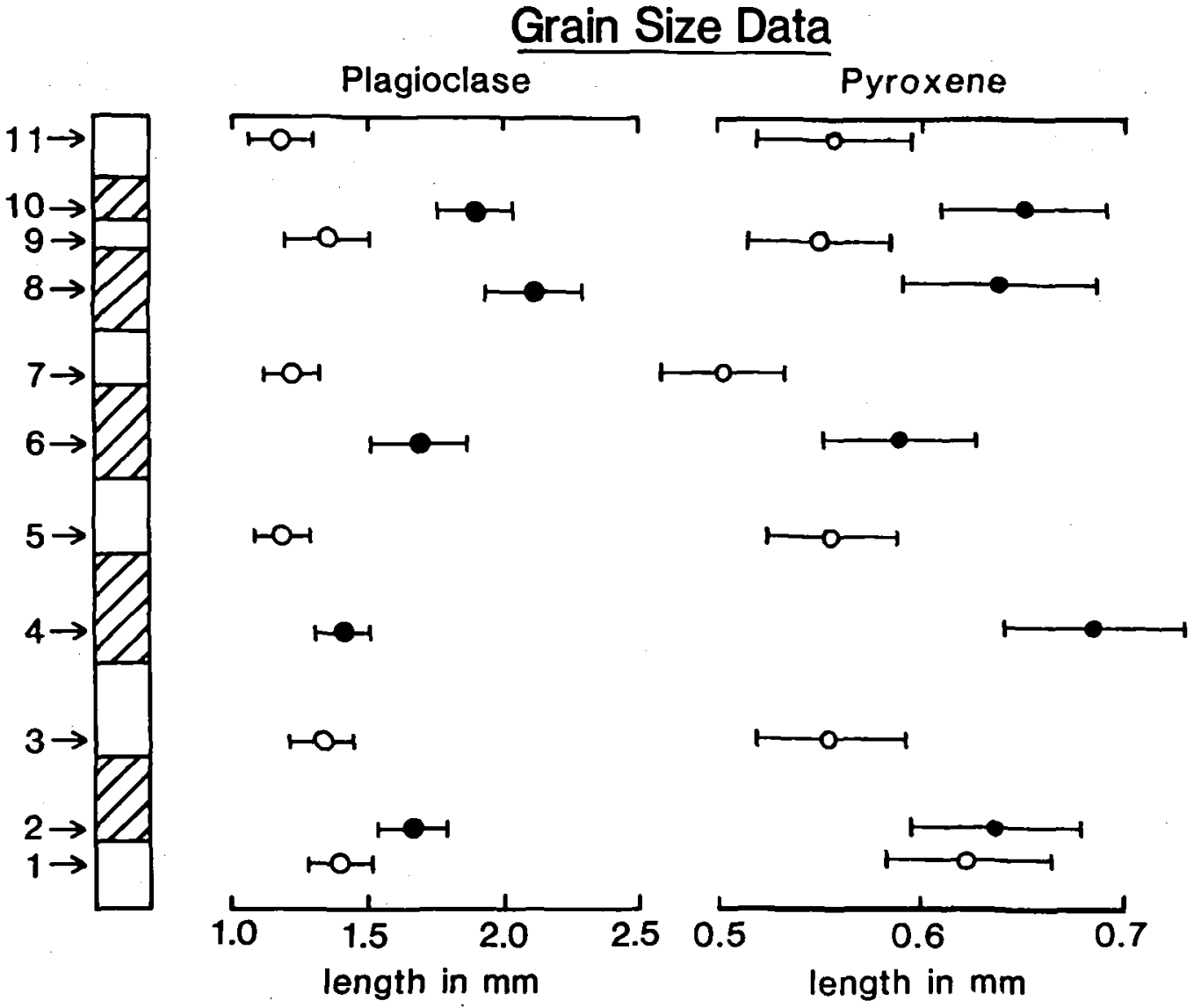

Fig. 4. Grain size variation in samples from the middle zone of the Skaergaard intrusion. Average grain sizes are based on measurements of 150 to 200 plagioclase grains and 100 pyroxene grains per sample.

\section{Modally-graded layers}

Modally-graded layers range from 1 to $10 \mathrm{~cm}$ thick, have sharp lower boundaries and gradational upper boundaries, and are internally graded. Individual layers are of variable thickness and in general can not be traced laterally for more than $30 \mathrm{~m}$ in outcrop. The modal abundance of opaque minerals varies within the layers from $20-25 \%$ at the base to $5-10 \%$ at the top; the modal abundances of plagioclase and pyroxene increase upward within the layers. Modallygraded rhythmic layers occur within both plagioclase-rich and pyroxene-rich macro-rhythmic layers with equal probability, and are in general parallel to the macro-rhythmic layer boundaries. There is no apparent correlation between the thicknesses of macro-rhythmic layers and the number of modally-graded layers that they con- tain. Sequences of modally-graded rhythmic layers exhibit numerous sedimentary-like structures including: truncations, low-angle cross bedding, channels, and bifurcations. Modally graded layers are much more abundant in the section examined on Kraemer Island which is approximately one $\mathrm{km}$ from the west margin of the intrusion than they are in a section from the same stratigraphic level on Pukugaqryggen which is $3 \mathrm{~km}$ from the nearest margin.

\section{Zone of Blocks}

A zone of autolith blocks in the middle zone of the Skaergaard intrusion are believed to have settled through the magma chamber as typical UBS gabbros and to have been selectively en- 
Table 1. Compositions of representative samples from the Kraemer island section.

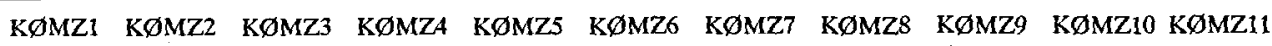

Oxide weight per cent

$\begin{array}{lrrrrrrrrrrr}\mathrm{SiO}_{2} & 48.5 & 38.2 & 47.7 & 38.4 & 47.3 & 45.3 & 45.7 & 36.2 & 47.1 & 38.8 & 41.3 \\ \mathrm{TiO}_{2} & 3.39 & 8.17 & 2.95 & 8.97 & 4.77 & 4.82 & 6.06 & 9.02 & 5.15 & 8.67 & 7.45 \\ \mathrm{Al}_{2} \mathrm{O}_{3} & 17.6 & 7.00 & 11.0 & 6.10 & 16.1 & 7.91 & 15.3 & 9.05 & 15.6 & 9.74 & 8.27 \\ \mathrm{Fe}_{2} \mathrm{O}_{3}{ }^{*} & 12.2 & 28.4 & 15.7 & 27.9 & 13.8 & 20.3 & 15.5 & 30.4 & 14.3 & 26.1 & 24.3 \\ \mathrm{MnO} & 0.15 & 0.30 & 0.24 & 0.31 & 0.17 & 0.29 & 0.18 & 0.28 & 0.18 & 0.26 & 0.27 \\ \mathrm{MgO} & 3.73 & 7.24 & 7.19 & 7.76 & 4.15 & 8.21 & 4.23 & 6.26 & 4.40 & 5.97 & 7.04 \\ \mathrm{CaO} & 10.5 & 10.1 & 12.1 & 10.3 & 10.3 & 12.2 & 9.82 & 8.51 & 10.4 & 9.52 & 10.6 \\ \mathrm{Na} 2 & 3.89 & 1.64 & 2.63 & 1.47 & 3.48 & 1.73 & 3.46 & 1.86 & 3.46 & 2.13 & 1.95 \\ \mathrm{~K}_{2} \mathrm{O} & 0.25 & 0.10 & 0.18 & 0.10 & 0.24 & 0.14 & 0.25 & 0.14 & 0.23 & 0.13 & 0.14 \\ \mathrm{P}_{2} \mathrm{O}_{5} & 0.06 & 0.03 & 0.05 & 0.05 & 0.06 & 0.07 & 0.07 & 0.03 & 0.08 & 0.03 & 0.05 \\ \text { total } & 100.27 & 101.18 & 99.74 & 101.36 & 100.37 & 100.97 & 100.57 & 101.75 & 100.9 & 101.35 & 101.37\end{array}$

Elemental weight in ppm

\begin{tabular}{lrrrrrrrrrrr} 
Sc & 33.8 & 69.4 & 64.2 & 77.6 & 39.4 & 74.9 & 41.6 & 53.6 & 42.1 & 57.5 & 66.8 \\
$\mathrm{Co}$ & 42.7 & 103 & 59.2 & 107.7 & 49.5 & 75.8 & 56.2 & 113.3 & 51.2 & 95.5 & 87.7 \\
$\mathrm{Rb}$ & 7.10 & 11.0 & 11.4 & 13.7 & 8.80 & 11.9 & 10.4 & 13.2 & 10.0 & 13.0 & 12.9 \\
$\mathrm{Sr}$ & 394 & 198 & 186 & 191 & 330 & 186 & 238 & 182 & 313 & 186 & 182 \\
$\mathrm{Zr}$ & 108 & 165 & 151 & 165 & 113 & 154 & 132 & 152 & 128 & 155 & 158 \\
$\mathrm{Cs}$ & 0.36 & 0.56 & 0.50 & 0.55 & 0.38 & 0.52 & 0.44 & 0.52 & 0.43 & 0.52 & 0.53 \\
\hline
\end{tabular}

* all $\mathrm{Fe}$ as $\mathrm{Fe}_{2} \mathrm{O}_{3}$

sample numbers from fig. 1 .

riched in plagioclase and depleted in mafic phases as a result of disequilibrium partial melting after deposition on the floor of the magma chamber (Naslund 1986). The autoliths range from $1 \mathrm{~m}$ to

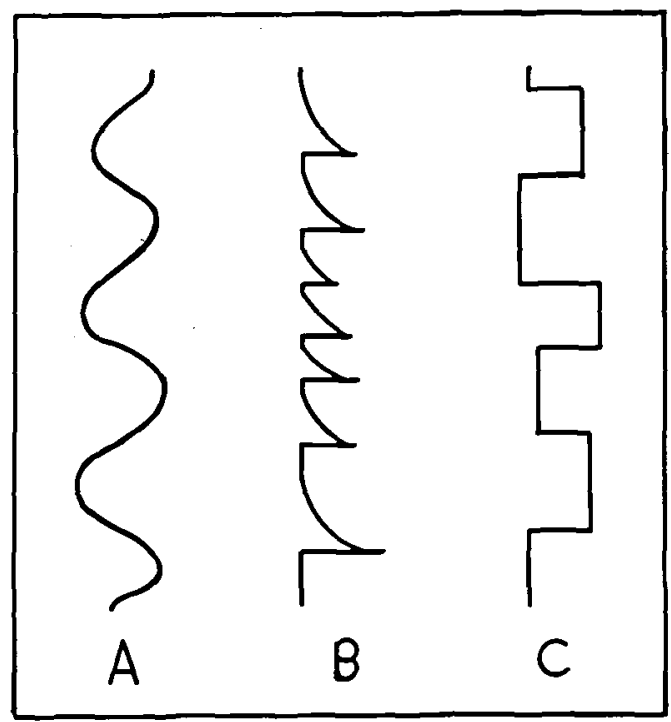

Fig. 5. Three types of processes that can occur in a magma chambers during crystallization. Type A - gradual changes between two extreme sets of conditions; type B - sudden changes in conditions followed by gradual reversals; type $\mathrm{C}$ - sudden changes in conditions followed by periods of stability and then sudden reversals.
$100 \mathrm{~m}$ in diameter and from gabbroic to anorthositic in composition. Many are more plagioclaserich than any rocks observed in the UBS and have calculated bulk densities lighter than that proposed for the middle zone magma (McBirney \& Noyes, 1979). Some autholiths are underlain by disrupted layering which indicates that layering formed at the crystal-liquid interface prior to the deposition of the autoliths. Other autoliths appear to have been remobilized as plagioclase crystal mushes and risen as diapirs disturbing overlying rhythmic layers, confirming that the layering formed prior to complete solidification.

\section{Discussion}

The macro-rhythmic layers record abrupt changes in the conditions of crystallization within the magma chamber, and suggest that the magma was well mixed because these changes appear to have occurred simultaneously over the entire intrusion. Three possible scenarios for changes in magma chambers are illustrated in fig. 5: plot A indicates a process which varies between two extreme sets of conditions; plot $B$ indicates a process in which a sudden change in conditions is 
followed by a gradual reversal to the old conditions; and plot $\mathrm{C}$ indicates a process which alternates between two sets of conditions. The macro-rhythmic layers appear to record a type $C$ process in the magma chamber. Assuming an average crystallization rate for the layered series of $2 \mathrm{~cm} / \mathrm{yr}$ (based on a solidification time for the entire intrusion of 130,000 years (Norton \& Taylor 1979)) the transitions between layers occurred in less than 1 year and each layer represents a crystallization interval of 15 to 165 years. Macrorhythmic layers may represent changes in the pattern of convection within the magma chamber with the pyroxene-rich layers corresponding to periods of increased convection and the plagioclase-rich layers corresponding to periods of stagnation.

In the system $\mathrm{Mg}_{2} \mathrm{SiO}_{4}-\mathrm{CaAl}_{2} \mathrm{Si}_{2} \mathrm{O}_{8}-\mathrm{Fe}_{3} \mathrm{O}_{4}-\mathrm{SiO}_{2}$ the equilibrium point between plagioclase, pyroxene, spinel, and liquid is shifted towards more plagioclase-rich compositions with increasing pressure (Osborn 1978). The static pressure change necessary to account for the difference in mode between adjacent macro-rhythmic layers would be impossible in the Skaergard intrusion. During convection, however, magma brought from lower-pressure to higher-pressure parts of the magma chamber will become oversaturated as a result of the pressure effect on liquidous temperatures and will precipitate pyroxene and Fe-Ti spinel to maintain equilibrium as a result of the shift in the equilibrium point towards more plagioclase-rich compositions. The coarser grain size and larger proportion of trapped liquid in the pyroxene-rich layers may have resulted from increased crystallization rates. The higher magnetite/ilmenite in the pyroxene-rich layers could have resulted from water-rich magma carried down from the upper parts of the magma chamber. Naslund (1984) suggested that the roof-zone magma is enriched in water relative to that at the floor. During periods of stagnant crystallization, plagioclase, pyroxene, and spinel should be precipitated in relative proportions controlled by equilibrium. The modal plagioclase/pyroxene in the plagioclase-rich layers (average 2.1) is closer to the equilibrium ratio in the system $\mathrm{Mg}_{2} \mathrm{SiO}_{4}-$ $\mathrm{CaAl}_{2} \mathrm{Si}_{2} \mathrm{O}_{8}-\mathrm{Fe}_{3} \mathrm{O}_{4}-\mathrm{SiO}_{2}$ (1.6-1.9) than is modal plagioclase/pyroxene in the pyroxene-rich layers (average 0.67).

Modally-graded rhythmic layers are most likely the result of interaction between magma currents and a zone of crystal accumulation on the floor of the magma chamber. The pattern of modal variation in the modally-graded layers follows a type $B$ process of fig. 5 indicating a sudden change of conditions followed by a period of gradual return to the prexisting conditions. Formation by intermittent density currents moving off the walls and across the floor of the intrusion would fit the observed data. The observation that the distribution of modally-graded layers is independent of the thickness or distribution of macro-rhythmic layers suggests that the modally-graded layers are not related to the same process of formation and, therefore, are probably not related to convection currents. The abundance of modally-graded layers near the margins of the intrusion support an origin from currents or slumps moving off the walls.

Acknowledgements. This research was supported by NASA grant *NAS5-28738 to HRN and by a grant from the Mansville Products Corporation. We are indebted to Dr. Michael D. Glascock at the University of Missouri research reactor for Neutron activation analysis. Discussions with D.E. Barnett, M. E. Conrad, T. N. Irvine, and A. R. McBirney were helpful in formulating some of the ideas presented here.

\section{Dansk sammendrag}

Et 23.3 meter mægtigt profil lokaliseret $i$ den nordlige del af Kræmer $\emptyset$ er blevet unders $\emptyset \mathrm{gt}$ for at klarlægge hvorledes den makro rytmiske og den modal graderede lagdeling i $\mathrm{MZ} i$ Skærgårds intrusionen er opstået.

De makrorytmiske lag danner 0.3 til 3.3 meter mægtige enheder domineret af skiftevis plagioklas og pyroxen. De enkelte lag er adskilt fra hinanden af en skarp kontakt og kan folges over afstande på $2 \mathrm{~km}$ parallelt med lagdelingen.

Koncentrationen af Ti-rige opaker er højest i de pyroxen dominerede lag, der yderligere er karakteriseret ved deres større kornstørrelse samt et øget indhold af indkompatible elementer ( $\mathrm{P}, \mathrm{Rb}, \mathrm{Zr}$ og $\mathrm{Cs})$, der formentlig skyldes større koncentrationer af interkumulus smelte $\mathrm{i}$ pyroxen dominerede lag end i plagioklas dominerede lag.

Termodynamiske overvejelser viser hvordan plagioklas/pyroxen forholdet i plagioklas dominerede lag ligger tæuttere pă ligevægts betingelserne i $\mathrm{Mg}_{2} \mathrm{SiO}_{4}-\mathrm{CaAl}_{2} \mathrm{Si}_{2} \mathrm{O}_{8}-\mathrm{Fe}_{3} \mathrm{O}_{4}-\mathrm{SiO}_{2}$ systemet end det tilsvarende forhold $i$ de pyroxen dominerede lag. De kunne således vare udfældet under roligere betingelser end de pyroxen dominerede lag, der tænkes udfældet i perioder med $ø$ get konvektion hvor smelter fra dybereliggende dele af magmakammeret $\mathrm{i}$ forsøg på at tilstræbe ligevægt, udfælder pyroxen og Fe-Ti spinel.

De modal graderede lag er lejret parallelt med de makrorytmiske lag som 1 til $10 \mathrm{~cm}$ mægtige strata, der kan følges over maksimum 30 meter parallelt med lagdelingen.

Koncentrationen af opaker graderer fra $20-25$ vol\% i bunden 
til 5-10\% opaker $i$ toppen og de enkelte lag forekommer både i pyroxen domineret og plagioklase domineret makrorytmiske lag.

Strukturer af samme karakter som dem man finder i alluviale aflejringer (krydslejringer m.m.), indikerer at de modal graderede lag kan være relateret til udglidning ned af væggen $i$ magma kammeret.

\section{References}

Conrad, M. E. 1982: Variations within the layering of the Skaergard intrusion, East Greenland. A. M. Thesis, Dartmouth College.

Irvine, T.N. 1980a: Magmatic density currents and cumulus processes. Amer. Jour. Sci. 280A, 1-58.

Irvine, T. N. 1980b: Observations on layering in the Skaergard intrusion. Yb. Carnegie Instn. Wash. 79, 257-262.

Irvine, T. N. 1982: Terminology for layered intrusions. Jour. Petrol. 23, 127-162.

Irvine, T.N. 1983a: Observations on the origin of Skaergaard layering. Yb. Carnegie Instn. Wash. 82, 284-289.
Irvine, T. N. 1983b: Skaergaard trough-layered structures, $Y b$. Carnegie Instn. Wash. 82, 289-295.

Lindsley, D. H. 1983: Pyroxene thermometry. Amer. Mineral. $68,477-493$.

McBirney, A.R. \& Noyes, R.N. 1979: Crystallization and layering of the Skaergard intrusion. Jour. Petrol. 20, 387554.

Naslund, H. R. 1984: Petrology of the Upper Border Series of the Skaergard intrusion. Jour. Petrol. 25, 185-212.

Naslund, H. R. 1986: Disequilibrium partial melting and rheomorphic layer formation in the contact aureole of the $\mathrm{Ba}$ sistoppen sill, East Greenland. Contrib. Mineral. Petrol. 93, 359-367.

Norton, D. \& Taylor, H.P. Jr., 1979. Quantitative simulation of the hydrothermal systems of crystallizing magmas on the basis of transport theory and oxygen isotope data: an analysis of the Skaergard intrusion. Jour. Petrol. 20, 421-486.

Osborn, E. F. 1978: Changes in phase relations in response to change in pressure from $1 \mathrm{~atm}$ to $10 \mathrm{kbar}$ for the system $\mathrm{Mg}_{2} \mathrm{SiO}_{4}$-iron oxide- $\mathrm{CaAl}_{2} \mathrm{Si}_{2} \mathrm{O}_{8}-\mathrm{SiO}_{2}$. Yb. Carnegie Instn. Wash. 77, 784-790.

Wager, L. R. \& Brown, G. M. 1968: Layered Igneous Rocks. San Francisco, CA: W. H. Freeman \& Co. 